\title{
Targeting of Asian Americans and Pacific Islanders by the tobacco industry: results from the Minnesota Tobacco Document Depository
}

\author{
M E Muggli, R W Pollay, R Lew, A M Joseph
}

See end of article for authors' affiliations

.....................

Correspondence to: Anne M Joseph, MD, MPH, VAMC $\left(\begin{array}{lll}1 & 1 & 1-0\end{array}\right)$ One

Veterans Drive

Minneapolis, MN 55417,

USA;

Anne.M.Joseph@med.va.gov

Received 12 March 2001

and revision requested

10 May 2001.

Accepted 24 May 2002

\begin{abstract}
Objective: The study objective was to review internal tobacco industry documents written between 1985 and 1995 regarding the Asian American and Pacific Islander (AAPI) population in the USA. These documents detail opportunities and barriers to promotion of tobacco products, as viewed by the tobacco industry and its market research firms.

Data sources/methods: Researchers reviewed tobacco industry documents from the document depository in Minneapolis, Minnesota and the tobacco industry's website, The Tobacco Archive, in a systematic fashion. A combined technique was employed using title keywords, dates, and names to search the $4(b)$ index.

Findings: A review of internal tobacco company documents reveal that during the late 1980s, the industry and its market research firms recognised the importance of the AAPI community as a potential business market. Documents describe the population growth in this community, the high prevalence of smoking in countries of origin, high purchasing power of AAPI immigrants, cultural predisposition to smoking, opportunities afforded by the high proportion of retail businesses under AAPI ownership, barriers to developing the AAPI market, comprehensive campaigns, and political and lobbying efforts. Comprehensive campaigns were designed to integrate promotion efforts in AAPI consumer, retail, and business communities.

Conclusions: The documents show that the tobacco industry developed specific promotion strategies to target the AAPI population. Tobacco control initiatives in the AAPI group have been slower to develop than in other targeted ethnic groups, and may benefit by increased awareness of industry methods to promote tobacco use.
\end{abstract}

S uccess in the modern cigarette market comes less from mass marketing than from the careful cultivation of many smaller segments, such as those defined by sex, ethnicity, health beliefs, or psychographic type (for example, "virile women" of Dakota). This review of internal, once secret, tobacco company documents tells the story of how US tobacco companies recognised the emergence of the Asian American and Pacific Islander (AAPI) segment as a potential market. The documents also detail the opportunities and barriers inherent in marketing to this diverse community, and disclose the wide ranging efforts put forth by the tobacco industry to target the AAPI market.

According to the US Department of Commerce, from 1980 to 1990, the AAPI population grew from an estimated 3.5 million to approximately 7 million, and represented a younger median population ( 30 years) than the national average (33 years). ${ }^{1}$ The six largest subgroups of Asian Americans are people of Chinese, Filipino, Japanese, Asian Indian, Korean, and Vietnamese descent, while the three largest Pacific Islander subgroups are Hawaiians, Samoans, and Guamanians. ${ }^{1}$ This dramatic increase in migration from parts of Asia to the USA was concentrated in major urban areas. Almost $66 \%$ of Asian Americans live in California, Hawaii, Illinois, New York and Texas, while approximately $75 \%$ of Pacific Islanders live in California and Hawaii. ${ }^{1}$

Although there are limited published data to show how the tobacco industry has targeted the AAPI population, there is evidence that it has targeted other minority groups; especially African Americans, Hispanics, women, gay lesbian communities, youth, and blue collar populations. ${ }^{2-4}$ Previous research on cigarette promotion has looked at various components of the marketing mix, but has concentrated on advertising. Topics have included the content of cigarette ads, ${ }^{5}$ imagery design, ${ }^{6}$ effectiveness of advertising warnings, ${ }^{7}$ advertising agency operations, ${ }^{8}$ effects of bans and major restrictions, ${ }^{9}$ and the failures and shortcomings of self regulation. ${ }^{10} 11$ Other research has examined special forms of communications, such as sports sponsorship, ${ }^{12}{ }^{13}$ product placement and smoking in films, ${ }^{14}{ }^{15}$ public relations, ${ }^{16}{ }^{17}$ retail signage ${ }^{18}$ and billboards or outdoor advertising. ${ }^{19}$

It has been noted from US studies conducted in San Francisco, ${ }^{20}$ St Louis, ${ }^{21}$ Chicago, ${ }^{22}$ San Diego, ${ }^{23}$ Boston, ${ }^{19}$ and nationwide ${ }^{24}$ that billboard cigarette advertisements are three to five times more prevalent in ethnic minority communities than in white communities. Ethnicity and race of models in advertisements consistently matches that of the neighbourhood. ${ }^{19}$ In a study comparing advertising in Asian, Hispanic, African American, or white neighbourhoods, Asian stores were significantly more likely to have tobacco advertising outside stores, and ads inside and outside stores were significantly less likely to have health warnings in Asian, Hispanic, and Black neighbourhoods than in white neighbourhoods. ${ }^{23}$ The highest proportion of tobacco billboards in San Francisco were posted in AAPI communities and the lowest proportion were found in white neighbourhoods. ${ }^{25}$

Tobacco products are also heavily promoted to ethnic minority groups in print advertising. Studies have compared the relative frequency of advertising, use of ethnic models, and advertising content in magazines with predominantly black readership (such as Ebony, Jet, and Essence) to magazines with predominantly white readership (such as Life). Magazines such as Ebony had less tobacco advertising in the 1950s, but this changed beginning in the 1960s. ${ }^{26}$ 
To date, however, research on targeting ethnic minority groups has concentrated on African American and Hispanic minority exposure; AAPIs are a more recent addition to the special target market. The 1998 US Surgeon General's report, entitled "Tobacco use among US racial/ethnic minority groups: African Americans, Indians and Alaska Native, Asian Americans and Pacific Islanders, and Hispanics", was the first major report to include the tobacco industry's marketing practices aimed at the AAPI population. ${ }^{25}$

This review of internal tobacco company documents written between 1985 and 1995 details the opportunities and barriers to promoting tobacco products to AAPIs, as viewed by the tobacco industry and its market research firms, and describes marketing strategies used to target this population. This description is intended to be useful to tobacco control efforts addressing this ethnic population.

\section{METHODS}

On May 8, 1998 the tobacco companies announced a settlement exceeding US\$6 billion with the state of Minnesota and Blue Cross Blue Shield of Minnesota from a lawsuit claiming the industry violated state antitrust and fraud statutes. As part of the Minnesota settlement, a document depository was created in Minneapolis, Minnesota to house over 32 million pages of internal tobacco documents. British American Tobacco was also required to provide public access to its approximate 8 million internal documents produced during the Minnesota litigation in a depository near Guildford, UK.

\section{Document acquisition}

Documents were acquired from two sources: The Minnesota Tobacco Document Depository, ${ }^{27}$ and the tobacco industry's web site, The Tobacco Archive. ${ }^{28}$

Approximately 200 boxes of industry documents were reviewed by one of the authors (MEM) from July 1998 to February 1999. The Minnesota Tobacco Document Depository estimates each box contains approximately 2500 pages.

\section{Minnesota Tobacco Document Depository}

The 4(b) Index was searched at the Minnesota Tobacco Document Depository utilising Basis Plus software. The 4(b) Index was created by the US defendants named in State of MN et al vs. Philip Morris et al and catalogues the documents by specific fields such as author, recipient, copyee, document date, title keyword(s), plaintiff request number, and document type. Separate indices were searched for the American Tobacco Company, Brown \& Williamson, Council for Tobacco Research, Inc, USA, Lorillard Tobacco Company, RJ Reynolds Tobacco Company, Philip Morris Incorporated, and the US Tobacco Institute.

\section{Tobacco Archives website}

The Tobacco Archives website (Tobaccoarchive.com), previously known as the Tobacco Resolution website, was created in 1998 by Philip Morris, RJ Reynolds, Lorillard Tobacco Company, Brown and Williamson, the US Tobacco Institute, and the Council for Tobacco Research, Inc, USA. Documents found at the industry's website represent material produced during State of MN et al vs. Philip Morris et al, documents produced between 23 October 1998 and 30 June 2010, and will contain documents from future litigation.

\section{Search methodology}

Measures were implemented to ensure as thorough a search of the 4(b) Index as possible. We employed a combined technique using title keywords, dates, and people named as an author, recipient, and/or copyee. The selected topic (that is, Asian Americans) and related terms (that is, market research) were searched as title keywords. The selected searched document was requested and reviewed, as well as the remainder of the box contents, because there are frequently other documents associated with the selected search (such as letters, memos, and speeches) that are not titled or dated, and therefore do not show up in the 4(b) Index search. Beginning with a search by title keywords allows for identification of key advertising agencies, promotions, and corporate affairs staff. Once additional persons, dates, and key words were identified, the 4(b) Index was further searched by author, recipient, copyee, and date. Search terms included the following: "Frasersmith", "Loiminchay", "L3", "Asian Perspective", "Special Markets", "DeLaura, EF", "Rodriguez, Y", "Fallis, C", "Chinese American", "SE 555", "Chinese New Year", "Korean", Vietnamese", and "API."

The Tobacco Archive website uses the National Association of Attorneys General (NAAG) index. The NAAG index is similar to the 4(b) Index except that the documents are searchable by people and organisations mentioned within the text of the document by two additional fields: named organisation, and named person. Documents were searched by combined text searches of author, recipient, copyee, named organisation, named person, title, and date, located at the Minnesota Tobacco Document Depository, and the document and the box containing the searched document was reviewed (See Search methodology section).

\section{FINDINGS}

\section{Opportunities in the AAPI market}

From 1988 to 1995, Philip Morris, RJ Reynolds, Lorillard Tobacco Company, and Brown and Williamson studied the AAPI market through various US based marketing research firms. ${ }^{29-38}$ In 1988, the tobacco industry's US leader, Philip Morris, retained the marketing firm of FraserSmith to conduct a market study on the AAPI consumer market and concluded that there was " . . .a significant opportunity in all Asian development areas" due to its population growth in the USA. $^{39}$ FraserSmith reported that AAPIs would "represent about 10 million people by the year 2000 " and that:

"[The] market is large enough to justify business investment that can produce short- and long- term gains for Philip Morris USA and other Philip Morris corporate divisions with a synergistic development approach." 40

Not only were AAPIs reported to be the fastest growing population in the US, but research also showed that they were geographically clustered within US cities, allowing more efficient targeting of the population. ${ }^{41}{ }^{42}$

Documents also suggest that because of higher smoking rates in their home countries, AAPI smokers would be a viable market in the USA. For example, an internal Philip Morris memo entitled, "U.S. Asians" discussed Benson and Hedges marketing opportunities in the AAPI community and reported the following:

\section{"Asian smokers appear to be a key market to focus on - since, according to Philip Morris International, smoking incidence in most Asian countries is considerably higher than that of the U.S." ${ }^{43}$}

Likewise, the Asian market research specialists, Loiminchay, reported the following to Lorillard Tobacco Company in 1990:

\begin{abstract}
"Other tobacco companies are aware that this community general[ly] [sic] predisposed toward smoking, is a potential gold mine." 44
\end{abstract}

In addition to a "predisposition toward smoking", the market research firms indicated that the AAPI community had increased consumer purchasing power compared to other 
minority groups, and demonstrated strong brand loyalty due to desired acculturation. For example, RJ Reynolds conducted a study in the late 1980s which aimed to "provide information usable in determining whether the Asian American market presents . . a marketing opportunity for RJR Tobacco", ${ }^{45}$ and reported the following:

"[T]hree values/beliefs [family, education and strong work ethic] are important to Asian Americans because they believe they will ultimately result in the achievement of their main objective - to effectively assimilate into U.S. culture/lifestyles. This desire to assimilate leads, in turn, to a high level of identification with those products and symbols which they view as 'American.' Importantly, this identification leads to brand name purchasing patterns and a highly developed sense of brand loyalty. "46

The RJ Reynolds' market study concluded with the following:

"Keeping in mind the high degree of brand loyalty shown by this market segment, if this target group were deemed an opportunity, actions should be taken to ensure that RJR is the first tobacco company to specifically target this group." ${ }^{47}$

RJ Reynolds was also optimistic that a strong cultural community identification and a consumer interest in sports and entertainment would allow for traditional targeting techniques, such as using Asian models in advertising and reaching the community through promotions and advertising strategies.

" . . . [T]he Asian American typically holds a strong belief in the value of the family. This sense of the importance of family reaches beyond the nuclear family to the extended family and often translates into a strong identification with the community. As a result, Asian Americans have traditionally centered their lives close to home in enclaves of other Asian Americans. Additionally, this identification with family/community tends to enhance their receptivity to ads using Asian models." ${ }^{47}$

"Many avenues are available to provide events and themes to motivate the Asian market. Examples are golf, motor sports, music, film, dance, and gambling . . Existing Asian events have not received major sponsorships and have been only operating at local community levels - Outstanding opportunities exist for building of new events which are proprietary to Philip Morris in reaching its target market without clutter of competitive freestanding, independently promoted Asian events. ${ }^{\prime \prime 8}$

Finally, the documents reveal that the tobacco companies recognised the unique opportunities the AAPI business community presented because of the high percentage of retail business owners. ${ }^{41}$ FraserSmith reported to Philip Morris that in 1987 Asian Americans owned approximately 355331 businesses in the USA and had revenues of $\$ 33$ billion. ${ }^{49}$ According to FraserSmith, the majority of convenience stores (80\% in the District of Columbia, $80 \%$ in New York City, and 1000 stores in Southern California) were "owned and operated by Asian retailers" in 1988. ${ }^{50}$ RJ Reynolds' market research attributed this high percentage of business ownership in the Asian American community to a strong work ethic. ${ }^{48}$ In addition, FraserSmith reported that convenience stores were responsible for a large portion of cigarette sales in the USA, and that Philip Morris should protect its business in this area.

\begin{abstract}
"Asian businesses are concentrated in the convenience store retail segment, where in 1987, an estimated $30 \%$ of the US consumer retail cigarettes purchases were made. This is a critical trade class in which Philip Morris needs to protect its higher level of share development and strengthen its position to grow. ${ }^{151}$
\end{abstract}

Retail store ownership appears to be a unique attraction of this ethnic target group. The sales force routinely visits stores to monitor retail promotional activity, displays, and inventory for the firm's own brands and those of the competition, in addition to delivering new inventory, taking orders, etc. Offers of promotional materials are made to the retailers, along with monetary incentives for cooperating with the promotional programmes of the manufacturers. These are typically not cash, but rather adjustments to what amounts are due for the goods supplied, and are known by various terms such as "promotional allowances", "discounts", or "slotting fees". These are sometimes single payments, but often are recurring-that is, paid periodically for as long as the promotional item is in use. Major items, such as fancy clocks, store awnings, etc, can be provided "free" or at greatly reduced costs to the retailer.

\section{Barriers to developing the AAPI market}

Although the industry viewed the AAPI target market as a potentially profitable business initiative, documents disclose that the tobacco companies recognised that there were significant challenges to reaching this market. By far the most important problem was creating a single advertising and promotion theme that would speak to the various distinct ethnic and language groups (approximately 30) in the AAPI population. $^{52}$ Unlike other media campaigns directed at African American and Hispanic communities, RJ Reynolds recognised the difficulty in speaking to this heterogeneous group.

"Cultural and language difference may prevent using a single marketing campaign to reach all Asian Americans. Many Asians, especially Southeast Asians, are even unfamiliar with the concept of advertising. ${ }^{\prime 47}$ [emphasis in original.]

Philip Morris also recognised linguistic and cultural diversity as a barrier to direct marketing to the AAPI community.

". . . [T]here are still some drawbacks to addressing this market directly. This is a very difficult population for directed marketing because of its cultural and linguistic diversity. In reality, the Asian-American market is a composition of many micro-markets, each with different values, desires, purchasing patterns, etc ..." ${ }^{43}$

The documents also reveal that slow acculturation among new immigrants, especially acquiring fluency in the English language and American customs, represented a significant hurdle for promotional campaigns. In fact, acculturation status would determine the accessibility of the market through traditional media and marketing strategies.

\footnotetext{
"'First Generation' Asians are important because they represent potential new smokers. However, they are the most difficult to reach due to language and cultural factors. - Later generations are more assimilated and easier to reach by mainstream brand marketing and media approaches." ${ }^{113}$
}

Finally, the absence of well developed AAPI media needed for effective communication represented a major drawback to targeting this community. 


\begin{abstract}
"Because the Asian media is not well developed, communications to the market is comprised of community networking and word-of-mouth. - Entry to the community has to be done on several different levels to be effective." ${ }^{54}$
\end{abstract}

\section{A comprehensive marketing campaign}

After researching the business potential of the AAPI community, Philip Morris' marketing firm, FraserSmith, recommended a multifaceted strategic action plan including three distinct initiatives; the "PUSH strategy", the "PULL strategy", and the "CORPORATE GOODWILL strategy".

\section{The PUSH strategy}

The PUSH strategy took advantage of the AAPI market as both retailers and consumers. It was aimed at trade relations and business development, and consisted of three tactical components: (1) cultural "sensitivity programs" for the Philip Morris sales force; (2) special retail sales material; and (3) special "business to business" programmes. ${ }^{55}$

According to FraserSmith, the cultural sensitivity programme was needed because of cultural differences between the way AAPI retailers and Philip Morris employees conducted business.

"Philip Morris and other major manufacturers do not have an understanding of the Asian culture and, therefore, lack sensitivity needed to build complete relationships with these retailers. [The] American objective is to 'close the deal fast' versus Asian objective of 'establishing a relationship first', thereby building a foundation for a long-term business relationship."

The sensitivity programmes were implemented in key areas such as Philip Morris' sales offices in Los Angeles, and corporate executive offices in New York and California. ${ }^{57}$ A one day "awareness session" for corporate executives and a two day training session for sales force personnel were developed. ${ }^{58}$

The second tactical component-"special retail sales material" —was developed to "provide Asian retailers with a better understanding of merchandising techniques and an appreciation of the potential of Philip Morris products and marketing activities" ${ }^{59}$ It was recommended that visual components be used broadly as a means of overcoming language barriers. ${ }^{58}$

The third tactical strategy was the "special business to business support programmes" which had the following objective:

"Develop a 'preferred status' among Asian businessmen for Philip Morris so that its retail programs can be favorably supported by members of chambers of commerce, grocers associations and other local and national business organizations... Philip Morris would become a business partner with Asian business groups in the development of marketing programs that would be offered to their members." 59

The programmes would identify and address the needs of Asian business groups in California with financial management seminars, and organisational and administrative support. ${ }^{60}$

\section{The PULL strategy}

FraserSmith's second strategy, the PULL strategy, was aimed at consumer development through research, promotion, and advertising activities in the six largest Asian AAPI target population groups: Chinese, Japanese, Korean, Vietnamese, Filipino, and Asian Indian populations. ${ }^{61}$ The main PULL strategies were promotional events, brand targeting, events that appealed to youth, and culturally sensitive advertising methods.

Nisei Week Japanese Festival in Los Angeles was the first of many promotional events by Philip Morris that targeted the AAPI community. ${ }^{62}$ Merchandising opportunities included distribution of Marlboro products and samples from a festival booth, exhibition of a Marlboro Indianapolis 500 type car, and an honorary plaque presentation to two sponsored business organisations: Little Tokyo Business Association and Japan Business Association. ${ }^{63}$ Table 1 details further events in an RJ Reynolds report entitled "1988 Philip Morris Asian/Pacific American Special Events Program - New York", which outlined AAPI promotions in the key markets of New York, Southern California, and Northern California. ${ }^{64}$

Specific brand targeting was integral to the industry's advertising and promotional strategies and further evidenced implementation of a PULL strategy. According to several industry reports, Philip Morris' Marlboro cigarette was the most popular cigarette smoked in the AAPI market.

\section{"Its [Marlboro] broad popularity among Chinese- Americans along with its strong American imagery of cowboys, strength and adventure were cited as a direct influence on their choice to smoke that brand." 65}

The primary means by which Philip Morris targeted Marlboro cigarettes to the AAPI community was by conducting retail product promotions during community celebrations. For example, during the 1994 Chinese-Korean Mid Autumn Harvest Festival, Philip Morris offered free ornamental ceramic ashtrays with a carton purchase in New York, Houston, Chicago, San Francisco, and Los Angeles and ensured all communication with the AAPI market was in the population's respective language. ${ }^{66}$

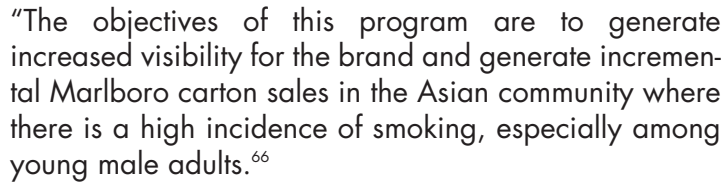

The documents show that Chinese New Year was also a significant marketing tool used to reach Chinese Americans. In 1992, Philip Morris offered a free party lighter with a Marlboro carton purchase in New York's Chinatown, Houston, Chicago, San Francisco, and Los Angeles, ensuring that all communication was in Chinese. ${ }^{67}$ According to a document found in Lorillard's files, Philip Morris also placed full page New Year's greeting messages containing the logos for all of its companies in the Chinese magazines. ${ }^{68}$

\section{The CORPORATE GOODWILL strategy}

The third strategy, CORPORATE GOODWILL, concentrated on community leadership and constituency building, with the objective of "build[ing] a positive image for Philip Morris by networking select community leaders and groups which are differentiated from business groups by their special interest focus." ${ }^{69}$ This strategy would target markets within the Asian groups such as women's groups, political groups, arts and culture, and senior citizens organisations headquartered in California and Washington DC. ${ }^{69}$ In addition, FraserSmith noted that a basic technique was to "develop a comprehensive directory of all Asian organisations similar to the Philip Morris' Black and Hispanic book of organisations, as a means to get the organisations to stimulate initial contact." ${ }^{\prime 70}$ A 1991 speech entitled "Minority Affairs Presentation to Jim Johnston" (then CEO of RJ Reynolds), indicates the necessity of reaching out to the minority community via corporate contributions. 
Table 1 Philip Morris' 1988 Asian American and Pacific Islander promotional activities ${ }^{64}$

\begin{tabular}{|c|c|c|c|c|}
\hline Event & Tobacco sampling & Age (years) & $\begin{array}{l}\text { Cost of promotion } \\
\text { event }\end{array}$ & $\begin{array}{l}\text { Projected } \\
\text { attendance }\end{array}$ \\
\hline Philippine Independence Day (New York) & Yes & AA & $\$ 8000$ & 10000 \\
\hline Philippine Independence Day (Southern California) & Yes & $21+$ & $\$ 7000$ & 10000 \\
\hline Festival of Santa Cruzan & Yes & $\mathrm{AA}$ & $\$ 5000$ & 5000 \\
\hline Gary Valencia Concert Tour & Yes & $18+$ & $\$ 19500$ & 24000 \\
\hline Chinese New Year festival and Celebration (New York) & Negotiable & $\mathrm{AA}$ & $\$ 7000$ & 25000 \\
\hline Korean Festival (New York) & Yes & $\mathrm{AA}$ & $\$ 8000$ & 15000 \\
\hline Asian American Food Festival & Yes & $18+$ & $\$ 10000$ & 10000 \\
\hline Union of Vietnamese Students Association TET New Year Festival & Yes & $18+$ & $\$ 11000$ & 30000 \\
\hline Little Tokyo 2nd Annual Bicycle Criterium & Negotiable & $18+$ & $\$ 5000$ & 7000 \\
\hline Little Tokyo Samurai 5K Race & Negotiable & $18+$ & $\$ 5000$ & 7000 \\
\hline Hawaiian Festival & Yes & AA & $\$ 10000$ & 40000 \\
\hline Sammy Hui Concert Tour & Yes & $18+$ & $\$ 17000$ & 19000 \\
\hline Korean festival (Los Angeles) & Yes & $\mathrm{AA}$ & $\$ 10000$ & 50000 \\
\hline Mayor's Asian Pacific American Heritage Festival Pop Music Series & Negotiable & $18+$ & $\$ 15000$ & 8000 \\
\hline Operation California Aid to Asian Concert Benefit at The Hollywood Bowl & Negotiable & $18+$ & $\$ 20000$ & 17500 \\
\hline Los Angeles Chinatown Firecracker $10 \mathrm{~K}$ Run & Negotiable & $21+$ & $\$ 5000$ & 6000 \\
\hline Philip Morris Young Asian/Pacific Adult Program & Yes & $18+$ & $\$ 55000$ & 50000 \\
\hline Southern California Chinese Grocers Association & Yes & $30+$ & $\$ 10000$ & $\mathrm{n} / \mathrm{a}$ \\
\hline Southern California Korean Grocers and Liquor Retailer's Association & Yes & $30+$ & $\$ 10000$ & $\mathrm{n} / \mathrm{a}$ \\
\hline All Nippon Golf Tournament/Nisei Week Festival & Yes & $30+$ & $\$ 15000$ & 1000 \\
\hline Japan Expo & Yes & $25+$ & $\$ 15000$ & 15000 \\
\hline TET New Year Festival, San Hose & Yes & $\mathrm{AA}$ & $\$ 10000$ & 45000 \\
\hline Taste of Asia & Yes & $21+$ & $\$ 7000$ & 10000 \\
\hline Cherry Blossom Festival & Negotiable & AA & $\$ 10000$ & 50000 \\
\hline Nihomachi Street Festival & Negotiable & $18+$ & $\$ 8000$ & 20000 \\
\hline San Francisco Chinese New Year Parade & Negotiable & $\mathrm{AA}$ & $\$ 20000$ & 300000 \\
\hline Pista Sa Nayon Celebration & Yes & $\mathrm{AA}$ & $\$ 10000$ & 20000 \\
\hline All Asia AM Golf Series & Yes & $30+$ & $\$ 15000$ & 2000 \\
\hline Asian American Jazz Festival & Negotiable & $21+$ & $\$ 20000$ & 10000 \\
\hline Chinatown YMCA 8K Race & Negotiable & $21+$ & $\$ 2500$ & 3000 \\
\hline
\end{tabular}

"Black and Hispanics traditionally link their trial and purchase of products, and their legislative and editorial support, directly to their understanding and belief that a company cares about their communities and issues. ${ }^{\prime 71}$

\section{RJ Reynolds and Brown \& Williamson strategies}

The documents reveal that other tobacco companies used similar promotional strategies: business outreach, direction of specific brands at ethnic youth markets, and replication of marketing methods that had proven successful in countries of origin. RJ Reynolds implemented a "minority business outreach" programme in 1991 in which 16 Asian organisations were selected to participate. In addition, RJ Reynolds Tobacco, Planters Lifesavers, and Nabisco held a purchasing seminar directed at minorities and businesses owned by women in New Jersey in 1991. ${ }^{72}$

The documents indicate that reaching a younger market was important for increasing specific brand sales in the AAPI population. According to a 1995 industry cigarette brand tracking study, Brown and Williamson's State Express (SE) 555 cigarette, a popular brand in Asia, trailed Philip Morris' Marlboro closely in second and third place among Vietnamese and Chinese adult smokers, respectively. ${ }^{38}$ Accordingly, Brown and Williamson's advertising agency, L3 Advertising, detailed a marketing plan for SE 555 cigarettes in the Asian American market. The plan asserted that, to achieve success in this market, Brown and Williamson would need to dissolve SE 555's older image and concentrate on attracting a younger clientele in the Asian American community.

". . . [U]ntil more aggressive initiatives are in place to attract a sizable base of younger adult smokers, the presence of current 555 customers, most of whom are older and more conservative, will somehow define $555^{\prime} \mathrm{s}$ image. ${ }^{173}$

\begin{abstract}
"Marlboro's series of youth-oriented promotions are posing real, present threats to 555's customer base. To balance their impact, 555 needs its own version of these hip, fun, exciting promotions. ${ }^{174}$
\end{abstract}

Strategies to reach a the youth market included an "Extended Rally Program". One component of this programme was the 555 Rally Clothing Competition, which included the following elements:

\begin{abstract}
"To exploit the Rally element further, with a bow to Asian Americans' extensive involvement in the fashion industry on both coasts, Asian American designers will be invited to participate in a fashion competition, including a benefit fashion show. A series of active, sporty clothing will arouse a great deal of interest and excitement and help revitalize 555's brand image. Free media coverage can definitely be generated, and a line of inexpensive 555 Rally clothing can be sold, given away and serve as uniforms." ${ }^{175}$
\end{abstract}

Other "Rally" events included distribution of 555 promotional video games due to the "many cafes in the Vietnamese community where video games are played by Vietnamese young adults". ${ }^{76}$ In addition, the plan called for "555 Phone Centers" to be placed in malls or other recreational areas where cigarettes, merchandise and phone cards would be sold. ${ }^{76}$ A “555 Rally club via direct mail" newsletter that would serve to update members on Rally events was also suggested. In addition, "555 Nights" was recommended to reach a younger market through organised dance parties in Los Angeles, New York, and San Francisco. ${ }^{76}$ It is unclear from the documents which of the 555 Rally initiatives materialised.

Mild Seven brand cigarettes were also heavily promoted to the AAPI community via billboard advertising and promotional sponsorship. ${ }^{45}$ Loiminchay advertising agency reported 
that, despite Benson \& Hedge's absence in most Asian countries, "B \& H might be a good fit with Asians since they find upscale symbolism of status very appealing" ${ }^{77}$ Other cigarette brand marketing strategies included using Asian American models in advertisements, based on focus groups findings.

\section{"Chinese Americans were very positive about the use of Chinese language and Chinese models. They felt they contributed to more arresting advertising and were certain to give them more attention browsing newspa- pers and magazines. ${ }^{178}$}

It was suggested that businesses utilise cigarette brand marketing methods used in Asia where AAPI consumers may have had previous exposure. For example, the use of "cigarette girls who promote the cigarettes while walking down the street with a tray" was recommended, as this is a popular technique in Hong Kong. ${ }^{76}$ Finally, including women and youth in targeting efforts was suggested.

"Investigate the possibility of utilizing men and women and targeting youth in advertising strategies.. The literature suggests that Asian-American women are smoking more as they believe they should enjoy the same freedom as men."

According to an RJ Reynolds report entitled "Minority Relations Program", the most important initiative for a minority programme was to define and target communities with more than a $25 \%$ minority population. ${ }^{80} \mathrm{RJ}$ Reynolds' also distributed resources to business and professional organisations in the AAPI community. Among funds directed at various minority groups, AAPI contributions increased from $0 \%$ in 1990 to $10 \%$ in $1993 .{ }^{81}$ Accordingly, RJ Reynolds was the primary corporate sponsor of the 13th National Conference of the Organization of Chinese Americans, Inc, ${ }^{82}$ the National Association of Asian American Journalist, ${ }^{83}$ and the Organization of Chinese Americans. ${ }^{83}$

\section{Political support and lobbying activity}

The documents indicate that supporting merchant associations in return for political support on issues important to the industry, such as federal excise taxes and public smoking restrictions, was a tactic used in many ethnic minority communities. ${ }^{84}$ In 1993, the RJ Reynolds "Special Markets Team" met with the New York and Southern California chapters of Korean-American Grocers Association (KAGRO) regarding their support for fighting increases in the federal excise taxes, ${ }^{85}$ and agreed to be the sole sponsor of a KAGRO seminar. $^{86}$

"... [The seminar] would give us the opportunity to address the membership regarding the negative impact of an increase in the FET [federal excise tax]. The cost of this sponsorship would be approximately $\$ 10,000 \ldots{ }^{187}$

The memo also reported that KAGRO's Southern California chapter had asked for continued corporate sponsorship of "KAGRO's golf tournaments, fund raisers, conventions and other events". ${ }^{88}$ In May of 1994, all KAGRO chapter presidents attending a meeting between KAGRO and RJ Reynolds signed an anti-federal excise tax resolution. ${ }^{89}$ The resolution took the form of a petition that would be signed by customers who frequented the retail establishments of KAGRO.

"Because members of these organizations would be severely affected by a major state or federal excise tax increase, they are a natural constituency for our message. A special effort should be launched to enlist the support of the many minority-owned 'mom and pop' retail stores ... that could be driven out of business by a sizable FET [federal excise tax] increase. ${ }^{90}$

In addition to buying an anti-federal excise tax constituency through corporate sponsorship, merchant associations were also used to disseminate the industry's views against public smoking restrictions. ${ }^{91}$ Tom Griscom, in-house legal counsel for RJ Reynolds, reported a local city council initiative attacking smoking ban legislation in Tennessee at a national sales conference in 1994.

"The Memphis sales team quickly pulled together an impressive list of allies to confront the council. Contacts were made with the Tennessee and Memphis Restaurant Associations, the Korean-American Grocers, the Beale Street Merchants Association and the Black Business Association...The results were overwhelming. The smoking ban failed... And the bill's sponsor even voted against it!"

\section{Results of tobacco promotion efforts}

Data needed to assess long term trends in smoking among the AAPI population are very limited, because most national databases do not include detailed information on race and ethnicity, and are complicated by small sample sizes in subpopulations of the group..$^{25}$ These gaps make it difficult to assess accurately the impact of tobacco promotion campaigns to this community.

The 1997 National Health Interview Survey showed that adult smoking prevalence was lower among AAPIs (16.9\%) than among Hispanics (20.4\%), whites (25.3\%), African Americans (26.7\%), and American Indians and Alaska Natives $(34.1 \%) .^{93}$ The report also noted that smoking rates are much higher in AAPI men than women. In 1997, $21.6 \%$ of AAPI men smoked, compared with $27.4 \%$ of white men, while only $12.4 \%$ of AAPI women smoked compared to $23.3 \%$ white women. The US Surgeon General reported in 1993 that lung cancer was the leading cause of cancer death (22.3\%) among AAPIs. ${ }^{25}$ The American Legacy Foundation (ALF), in collaboration with the Centers for Disease Control and Prevention, recently reported that the number of Asian American teenagers who smoke increased from $4.4 \%$ in middle school to $33.1 \%$ by grade $12 .{ }^{94}$ The ALF also noted that the increase in smoking rates is greater in Asian American youths than in any other ethnic group.

National studies that aggregate all AAPIs together, however, may be misleading. Local studies have shown that AAPI men from certain ethnic groups have some of the highest rates of smoking in the USA. Among Laotians, Cambodians, native Hawaiians, and Chuukese prevalence rates have been reported to be $72 \%,{ }^{95} 71 \%,{ }^{96} 42 \%,{ }^{97}$ and $53 \%,{ }^{98}$ respectively. In addition, national prevalence studies rarely account for smokeless tobacco, which is most commonly used in the AAPI community by chewing betel nut mixed with tobacco in a pepper leaf. ${ }^{99}$

\section{DISCUSSION}

The documents reveal that the AAPI community became a new priority for major tobacco sellers beginning in the 1980s. The documents also show that during the late 1980s and early 1990s, the tobacco companies undertook a major effort to explore whether the AAPI market would be a profitable endeavour. The industry's marketing firms indicated that this target market included the following opportunities: (1) increased population growth that was geographically localised; (2) high smoking prevalence in the countries of origin; 
(3) consumer and retail power; (4) cultural behaviours, such as interests in sports and community events; and (5) a desire to assimilate into "American culture". The marketing firms also detailed potential barriers to reaching this community, such as: (1) cultural and linguistic diversity; (2) level of acculturation; and (3) lack of community media outlets. Once satisfied that the AAPI population presented considerable business potential, the industry employed a wide range of marketing, promotion, and corporate sponsorship strategies to target the group. These included emphasis on the retail sales market in Asian owned stores, direct marketing of specific cigarette brands through community cultural events, youth orientated promotions, and corporate sponsorship.

Other evidence of the tobacco industry's special marketing efforts among minorities has been well documented, and share some features described in this review. These include modelling affluence and upward social mobility, support of community and business organisations, and minority specific advertising strategies. A unique feature of the industry's campaign to target this community is recognition of the strategic importance of the AAPI convenience store operators. The Asian retail market represents both resellers and consumers. As retailers, they are critical to overcoming advertising restrictions in other venues.

"Double targeting" this population in both the USA and its countries of origin was also a unique marketing tool the industry used to target AAPIs. The documents show that efforts were made to replicate familiar advertising strategies, such as "cigarette girls" and brand recognition strategies, to target those that may have had previous exposure in their native country.

Although the internal, once secret tobacco industry documents provide an invaluable source of information, there are inherent limitations to their acquisition and use. Firstly, full text searching is not available, therefore researchers rely on fields which can generate erroneous information and do not capture all of the documents produced related to AAPIs (only approximately 500000 pages were reviewed out of more than 40 million pages of available documents housed at the Minnesota and Guildford depositories. Secondly, of those 500000 pages of documents, only a fraction of the searched documents are cited here in the interest of presenting a concise report. Therefore, although we have tried to ensure that the quotations cited reflect the context of the document, this may not have been accomplished. Thirdly, there are large gaps in knowledge of the industry's activities with respect to marketing strategies due to the absence of privileged documents that were unavailable at the time of document acquisition and the absence of documents that were never produced during discovery. Fourthly, most of these documents were collected in litigation dating to before 1995, thus there are large gaps in knowledge of marketing activities after 1995. Finally, the physical state of the documents can also be problematic because of missing attachments, or legibility issues from multiple photocopying.

Tobacco document searching methods on-line have improved since documents were acquisitioned for this article. ${ }^{100}$ Since the Minnesota Tobacco Document Depository opened to the public in April of 1998, there has been an explosion of resources to accomplish document research. Documents can be searched on-line at The Centers for Disease Control, University of California, San Francisco, Health Canada, Physicians for a Smoke-Free Canada, and elsewhere. The authors recognise that the methodology employed to obtain documents for this article does not represent a complete as possible search due to improvements in document accessibility.

We recommend further document research in this area for several reasons: (1) since this review, additional documents have been produced to the Minnesota depository from other litigation; (2) in June of 2000, a Minnesota judge rejected

\section{What this paper adds}

Evidence shows that the industry has marketed tobacco products to specific ethnic minority groups. In particular, advertising campaigns directed at African Americans and Hispanics have been analysed. There is relatively little information about how the tobacco industry regards the Asian American market.

Tobacco industry documents reveal that the Asian American and Pacific Islander (AAPI) community became a new priority for major tobacco sellers beginning in the 1980s. The industry's marketing firms indicated that this target market included the following opportunities; population growth that was geographically localised, high smoking prevalence in the countries of origin, consumer and retail power, and a desire to assimilate to "American culture". The industry employed a wide range of marketing, promotion, and corporate sponsorship strategies to target the group including emphasis on the retail sales market in Asian owned stores, direct marketing of specific cigarette brands through community cultural events, youth orientated promotions, and corporate sponsorship.

claims of privilege for a subset of documents, therefore, over 200000 previously privileged documents are now housed in the Minnesota depository; and (3) the British American Tobacco depository in Guildford, UK was not searched for this review.

The documents reviewed confirm that the tobacco companies have targeted the AAPI community for over a decade. This review will assist in understanding how the industry viewed the AAPI community in the late 1980s and early 1990s and provides insight to tobacco control campaigns in the AAPI community. There are many efforts, primarily in California, to counter industry activities directed at AAPIs. The tobacco control capacity in areas of research and data, infrastructure, programmes, and policy in the AAPI community, however, is often characterised as lower than that of African American and Hispanic groups. ${ }^{101}$ Capacity development requires use of appropriate research methodologies that are culturally sensitive, model programmes, leadership, and a reflection of the historical context of the ethnic community. Programmes such as the Asian Partners for Empowerment and Leadership (APPEAL) are to be commended for their work to develop AAPI networks nationally. ${ }^{99}$

The AAPI tobacco control community faces many of the same challenges that the industry does, including remarkable language and cultural diversity among AAPI populations. The industry has developed valuable capacity to target AAPIs in the USA, and their findings also have implications for communities abroad. We recommend that tobacco control and education efforts try to use information from the tobacco industry documents to redress the damage that a decade of targeting has achieved.

\section{ACKNOWLEDGEMENTS}

Support was provided from the Blue Cross and Blue Shield Foundation of Minnesota.

\section{Authors' affiliations}

M E Muggli, Minneapolis, Minnesota, USA

R W Pollay, Faculty of Commerce, University of British Columbia, Vancouver BC, Canada.

R Lew, Association of AsianPacific Community Health Organizations, Oakland, California, USA.

A M Joseph, VA Medical Center and University of Minnesota, Minneapolis, Minnesota, USA 


\section{REFERENCES}

1 United States Department of Commerce. Bureau of the Census. Economic and Statistic Administration. We the Americans: Asians and Pacific Islanders. http://www.census.gov/apsd/wepeople/we-3.pdf, September 1993

2 Davis RM. Current trends in cigarette advertising and marketing. N Engl J Med 1987;316:725-32.

3 Goebel K. Lesbians and gays face tobacco targeting. Tobacco Control 1994;3:65-7.

4 Arday DR, Edlin BR, Giovino GA, et al. Smoking, HIV infection, and gay men in the United States. Tobacco Control 1993;2:156-8.

5 Pollay RW. Historical content analyses of cigarette advertising. Preventing tobacco use among young people. A report of the Surgeon General, 1994. Atlanta, Georgia: Public Health Service, Centers for Disease Control and Prevention, Office on Smoking and Health, 1994. (US Government Printing Office Publication No S/N 017-001-00491-0.)

6 Pollay RW. Export 'A' ads are extremely expert, eh? Tobacco Control 2000;10:71-4

7 Krugman DM, Fox RJ, Fletcher JE, et al. Do adolescents attend to warnings in cigarette advertising? An eye-tracking approach. J Advertising Research 1994; 34(6):3(14).

8 Hastings G, McFadyen L, Stead M. A day in the life of an advertising man: review of internal documents from the UK tobacco industry's principal advertising agencies. BM 2000;321:366-70.

9 Safer H, Chaloupka F. The effect of tobacco advertising bans on tobacco consumption. J Health Economics 2000;19:1 117-37.

10 Richards JW, Tye JB, Fischer PM. The tobacco industry's code of advertising in the United States: myth and reality. Tobacco Control 1997;6:1-17.

11 Barbeau EM, De Jong W, Brugge DM, et al. Does cigarette print advertising adhere to the Tobacco Institute's voluntary advertising and promotion code? J Public Health Policy 1998; 19:473-88.

12 Turco DM. The state of tobacco sponsorship in sport. Sport Marketing Quarterly 1999;8:35-8.

13 Blum A. The Marlboro Grad Prix: circumvention of the television ban on tobacco. N Engl J Med 1991;324:913-17.

14 Escamilla G, Cradock AL, Kawachi I. Women and smoking in Hollywood movies: a content analysis. Am J Public Health 2000;90:412-14.

15 Stockwell TF, Glantz SA. Tobacco use is increasing in popular films. Tobacco Control 1997;6:282-4.

16 Miller KS. Smoke and mirrors: public relations and the news media. The Voice of Business: Hill \& Knowlton and Postwar Public Relations. Chapel Hill: UNC Press; $121-45$

17 Pollay RW. Propaganda, puffing and the public interest: the scientific smoke screen for cigarettes. Public Relations Rev 1990;16:27-42

18 Cummings KM, Sciandre R, Lawrence J. Tobacco advertising in retail stores. Public Health Reports 1991; 106:570-5

19 Pucci LG, Joseph HM, Siegel M. Outdoor tobacco advertising in six Boston neighborhoods: evaluating youth exposure. Am J Prev Med 1998;15:155-9.

20 Altman DG, Schooler C, Basil MD. Alcohol and cigarette advertising on billboards. Health Education Research 1991;6:487-90.

21 Luke D, Esmundo E, Bloom Y. Smoke signs: patterns of tobacco billboard advertising in a metropolitan region. Tobacco Control 2000:9:15-23.

22 Hackbarth DP, Silvestri B, Cosper W. Tobacco and alcohol billboards in 50 Chicago neighborhoods: market segmentation to sell dangerous products to the poor. J Public Health Policy 1995; 16:213-30.

23 Wildey MB, Young RL, Elder JP, et al. Cigarette point-of-sale advertising in ethnic neighborhoods in San Diego, California. Health Values 1992;16:23-8.

24 McMahon ET, Taylor PA. Citizen's action handbook on alcohol and tobacco advertising. Washington DC: Center for Science in the Public Interest, 1990.

25 US Department of Health and Human Services. Tobacco use among U.S. racial/ethnic minority groups: African Americans, American Indians and Alaska Natives, Asian Americans and Pacific Islanders, Hispanics. A report of the Surgeon General, 1998. Atlanta, Georgia: Centers for Disease Control and Prevention, Office on Smoking and Health, 1998. (US Government Printing Office Publication No S/N 017-001-00527-4.)

26 Pollay RW, Lee JS, Carter-Whitney D. Separate, but not equal: racial segmentation in cigarette advertising. J Advertising 1992;21:45-57.

27 Minnesota Tobacco Document Depository. Hennepin Business Center, 1021 10th Avenue SE, Suite 1021, Minneapolis, MN, USA 55414 Phone: 1-800-526-8886 Email: Mndep@aol.com

28 The Tobacco Archive. http://www.tobaccoarchive.com, 1999.

29 Massler C. Asian Outdoor. 30 October 1991. Philip Morris Inc. 2041821639-1640. Minnesota Tobacco Document Depository.

30 Massler S. Re: Asian-American Market. 18 April 1991.Philip Morris Inc. 2041821641-1673. Minnesota Tobacco Document Depository.

31 Frasersmith. Philip Morris USA Asian-American Market Development. Undated. Philip Morris Inc. 2044744001-4037. Minnesota Tobacco Document Depository.

32 Prospectus Special Markets - Asian Americans. Undated. R.J. Reynolds Tobacco Company. 507757039-7046. Minnesota Tobacco Document Depository.

33 Loiminchay Advertising. Overview of Chinese-American Cigarette Market for Kent. Focus Groups Findings. 5 October 1992. Lorillard Tobacco Company. 87364495-4543. Minnesota Tobacco Document Depository.
34 Loiminchay Advertising. An evaluation of the field visit to Hong Kong and competitive advertising study for Kent Cigarettes. 2 October 1990. Lorillard Tobacco Company. 92044968-6047. Minnesota Tobacco Document Depository.

35 Asian Perspective, Inc. Focus group studies Chinese \& Vietnamese 555 users and non-users. November 1994. Brown and Williamson Tobacco Company. 502012447-2497. Minnesota Tobacco Document Depository

36 L3 Advertising, Inc. An ideal plan for Brown and Williamson in the Asian American market. 15 December 1995. Brown and Williamson Tobacco Company. 502010038-0047. Minnesota Tobacco Document Depository.

37 Asian Perspective, Inc. 555 general consumer survey 3rd quarter, 1994 results presentation for Brown \& Williamson. 13 April 1995. Brown and Williamson Tobacco Company. 502012409-2423. Minnesota Tobacco Document Depository.

38 Delaura EF. Asian focus groups. 26 August 1992. Lorillard Tobacco Company. 82887327. Minnesota Tobacco Document Depository.

39 Fallis MC. FraserSmith agency review. 5 August 1988. Philip Morris Inc. 2044733604-3704 at 3605. Minnesota Tobacco Document Depository.

40 Fallis MC. FraserSmith agency review. 5 August 1988. Philip Morris Inc 2044733604-3704 at 3669. Minnesota Tobacco Document Depository.

41 Fallis MC. FraserSmith agency review. 5 August 1988. Philip Morris Inc 2044733604-3704 at 3672. Minnesota Tobacco Document Depository.

42 Cohen D. Asian-American market study. 16 April 1993. Philip Morris Inc. 2042045106-5115 at 5112. Minnesota Tobacco Document Depository

43 Rodriguez Y. US Asians. 20 October 1993. Philip Morris Inc. 2042045100-5105 at 5100. Minnesota Tobacco Document Depository.

44 Loiminchay Advertising. An evaluation of the field visit to Hong Kong and competitive advertising study for Kent cigarettes. 2 October 1990. Lorillard Tobacco Company. 92044968-6047 at 5036. Minnesota Tobacco Document Depository.

45 Prospectus Special Markets - Asian Americans. Undated. R Reynolds Tobacco Company. 507757039-7046 at 7039. Minnesota Tobacco Document Depository.

46 Prospectus Special Markets - Asian Americans. Undated. R Reynolds Tobacco Company. 507757039-7046 at 7043. Minnesota Tobacco Document Depository

47 Prospectus Special Markets - Asian Americans. Undated. RJ Reynolds Tobacco Company. 507757039-7046 at 7042. Minnesota Tobacco Document Depository.

48 Fallis MC. FraserSmith Agency review. 5 August 1988. Philip Morris Inc. 2044733604-3704 at 3667. Minnesota Tobacco Document Depository.

49 Massler S. Re: Asian-American market. 18 April 1991. Philip Morris Inc $2041821641-1673$ at 1669. Minnesota Tobacco Document Depository.

50 Frasersmith. Philip Morris USA Asian-American market development. Undated. Philip Morris Inc. 2044744001-4037 at 4010. Minnesota Tobacco Document Depository

51 Frasersmith. Philip Morris USA Asian-American market development. Undated. Philip Morris Inc. 2044744001-4037 at 4015. Minnesota Tobacco Document Depository

52 Rodriguez Y. Hispanic and Asian market. 21 January 1991. Philip Morris Inc. 20491627287-2788 at 2787. Minnesota Tobacco Document Depository.

53 Frasersmith. Philip Morris USA Asian-American market development Undated. Philip Morris Inc. 2044744001-4037 at 4011. Minnesota Tobacco Document Depository.

54 Fallis MC. FraserSmith Agency review. 5 August 1988. Philip Morris Inc. 2044733604-3704 at 3664. Minnesota Tobacco Document Depository.

55 Frasersmith. Philip Morris USA Asian-American market development Undated. Philip Morris Inc. 2044744001-4037 at 4018. Minnesota Tobacco Document Depository.

56 Fallis MC. FraserSmith Agency review. 5 August 1988. Philip Morris Inc. 2044733604-3704 at 3665. Minnesota Tobacco Document Depository.

57 Frasersmith. Philip Morris USA Asian-American market development Undated. Philip Morris Inc. 2044744001-4037 at 4021. Minnesota Tobacco Document Depository.

58 Frasersmith. Philip Morris USA Asian-American market development Undated. Philip Morris Inc. 2044744001-4037 at 4024. Minnesota Tobacco Document Depository.

59 Frasersmith. Philip Morris USA Asian-American market development Undated. Philip Morris Inc. 2044744001-4037 at 4026. Minnesota Tobacco Document Depository.

60 Frasersmith. Philip Morris USA Asian-American market development Undated. Philip Morris Inc. 2044744001-4037 at 4027. Minnesota Tobacco Document Depository.

61 Frasersmith. Philip Morris USA Asian-American market development. Undated. Philip Morris Inc. 2044744001-4037 at 4028. Minnesota Tobacco Document Depository.

62 Frasersmith. Philip Morris USA Asian-American market development Undated. Philip Morris Inc. 2044744001-4037 at 4032. Minnesota Tobacco Document Depository.

63 Frasersmith. Philip Morris USA Asian-American market development Undated. Philip Morris Inc. 2044744001-4037 at 4029-4031. Minnesota Tobacco Document Depository. 
64 RJ Reynolds. Philip Morris' 1988 API Promotional Activities. 1988. RJ Reynolds Tobacco Company. 507091847-1851. Minnesota Tobacco Document Depository.

65 Loiminchay Advertising. Overview of Chinese-American cigarette market for Kent. Focus groups findings. October 5, 1992. Lorillard Tobacco Company. 87364495-4543 at 4498. Minnesota Tobacco Document Depository.

66 Von Moltke N. Chinese/Korean harvest festival retail promotion-elements. 7 August 1992. Philip Morris Inc 2048520764-0766 at 0764. Minnesota Tobacco Document Depository.

67 Von Moltke N. Chinese New Year - promotion elements. 13 January 1992. Philip Morris Inc. 2041356026-6028 at 6026-6027. Minnesota Tobacco Document Depository.

68 Asian National Media Plan. Undated. Lorillard Tobacco Company. 92045873-5875 at 5875. Minnesota Tobacco Document Depository.

69 Frasersmith. Philip Morris USA Asian-American market development. Undated. Philip Morris Inc. 2044744001-4037 at 4033. Minnesota Tobacco Document Depository.

70 Frasersmith. Philip Morris USA Asian-American market development. Undated. Philip Morris Inc. 2044744001-4037 at 4034. Minnesota Tobacco Document Depository

71 RJ Reynolds. Minority affairs presentation to Jim Johnston. 22 March 1991. RJ Reynolds Tobacco Company. 507701655-1665 at 1656. Minnesota Tobacco Document Depository.

72 RJ Reynolds Nabisco, Inc. Quarterly meetings agenda and background information minority relations program. 14 May 1991. RJ Reynolds Tobacco Company. 507767327-7409 at 7381. Minnesota Tobacco Document Depository.

73 L3 Advertising, Inc. An ideal plan for Brown and Williamson in the Asian American Market. 15 December 1995. Brown and Williamson Tobacco Company. 502010038-0047 at 0040. Minnesota Tobacco Document Depository.

74 L3 Advertising, Inc. An ideal plan for Brown and Williamson in the Asian American market. 15 December 1995. Brown and Williamson Tobacco Company. 502010038-0047 at 0042. Minnesota Tobacco Document Depository.

75 L3 Advertising, Inc. An ideal plan for Brown and Williamson in the Asian American Market. 15 December 1995. Brown and Williamson Tobacco Company. 502010038-0047 at 0046. Minnesota Tobacco Document Depository.

76 Loiminchay Advertising. An evaluation of the field visit to Hong Kong and competitive advertising study for Kent cigarettes. 2 October 1990. Lorillard Tobacco Company. 92044968-6047 at 5046. Minnesota Tobacco Document Depository.

77 Bonhonne B, Teitelbaum S. Weekly highlights (11-18 October) Premium Brands. 18 October 1993. Philip Morris Inc. 2048887261-7262 at 7261. Minnesota Tobacco Document Depository.

78 Loiminchay Advertising. Overview of Chinese-American cigarette market for Kent. Focus groups findings. 5 October 1992. Lorillard Tobacco Company. 87364495-4543 at 4499. Minnesota Tobacco Document Depository.

79 Loiminchay Advertising. An evaluation of the field visit to Hong Kong and competitive advertising study for Kent cigarettes. 2 October 1990. Lorillard Tobacco Company. 92044968-6047 at 5045-5046. Minnesota Tobacco Document Depository

80 RJ Reynolds Nabisco, Inc. Quarterly meetings agenda and background information minority relations program. 14 May 1991. RJ Reynolds Tobacco Company. 507767327-7409 at 7336. Minnesota Tobacco Document Depository.

81 RJ Reynolds Nabisco, Inc. Quarterly meetings agenda and background information minority relations program. 14 May 1991. RJ Reynolds
Tobacco Company. 507767327-7409 at 7337. Minnesota Tobacco Document Depository.

82 RJ Reynolds Nabisco, Inc. Quarterly meetings agenda and background information minority relations program. 14 May 1991. RJ Reynolds Tobacco Company. 507767327-7409 at 7393. Minnesota Tobacco Document Depository.

83 RJ Reynolds. Recommendations for 1993 Community Action Corporate (RJRN) Contributions. 1993. RJ Reynolds Tobacco Company. 51 1993955-3960 at 3960. Minnesota Tobacco Document Depository.

84 Duran JW. James W. Duran. Corporate affairs regional manager. 2nd quarter business plan. RJ Reynolds Tobacco Company. 511382015-2016 at 2015. Minnesota Tobacco Document Depository.

85 Griscom TC. RJ Reynolds Tobacco Company. 512688206-8212 at 8209. Minnesota Tobacco Document Depository.

86 Singleton, J. Special markets team status report. 29 Apri 1993. RJ Reynolds Tobacco Company. 511426820-6823 at 6820. Minnesota Tobacco Document Depository.

87 Singleton J. Special markets team status report. 29 April 1993. RJ Reynolds Tobacco Company. 511426820-6823 at 6820. Minnesota Tobacco Document Depository.

88 Singleton, J. Special markets team status report. 29 April 1993. RJ Reynolds Tobacco Company. 511426820-6823 at 6821. Minnesota Tobacco Document Depository.

89 Griscom T. 18 May 1994. R Reynolds Tobacco Company. 51 1425727-5733 at 5727. Minnesota Tobacco Document Depository.

90 Eagle Alliance Special Markets Team. FET and EPA recommendations Undated. RJ Reynolds Tobacco Company. 511426817-6819 at 6818. Minnesota Tobacco Document Depository.

91 National Smokers' Alliance. Confidential. National Smokers Alliance weekly report. 10 December 1993. Phillip Morris Inc. 2023202960-2984 at 2972. Minnesota Tobacco Document Depository.

92 Tom Grisom Luncheon Remarks. National sales conference. 12 January 1994 - Winston-Salem. 12 January 1994. RJ Reynolds Tobacco Company. $511413572-3603$ at 3598-3599. Minnesota Tobacco Document Depository.

93 Centers for Disease Control and Prevention. Cigarette smoking among adults - United States, 1997. MMWR Morb Mortal Wkly Rep 1999;48:993-6.

94 http://www.americanlegacy.org/community/displayRelease. January 2001.

95 Levin B, Nachampassach S, Xiong R. Cigarette smoking and the Laotian refugee. Migrant World 1988;16(4):33-5.

96 Rumbaut RG. Portraits, patterns and predictors of the refugee adaptation process. In: Haines DW, ed. Refugees as immigrants. Totowa, New Jersey: Routtan and Littlefield, 1989

97 Curb JD, Aluli NE, Kautz JA, et al. Cardiovascular risk factor levels in ethnic Hawaiians. Am J Public Health 1991;81:164-7.

98 Marshall $M$. The second fatal impact: cigarette smoking, chronic disease, and the epidemiological transition in Oceania. Soc Sci Med 1991;33:1327-42

99 Lew R. A national effort to reduce tobacco use among Asian Americans and Pacific Islanders. Sixth Biennial Symposium on Minorities, the Medically Underserved \& Cancer. Cancer 1998 (suppl): 1818-20.

100 Malone RE, Balbach ED. Tobacco industry documents: treasure trove or quagmire? Tobacco Control 2000;9:334-8.

101 Robinson RG, Shelton DM, Hodge F, et al. Tobacco control capacity index for communities of color in the United States. In: Slama K, ed. Tobacco and Health. New York: Plenum Press, 1995

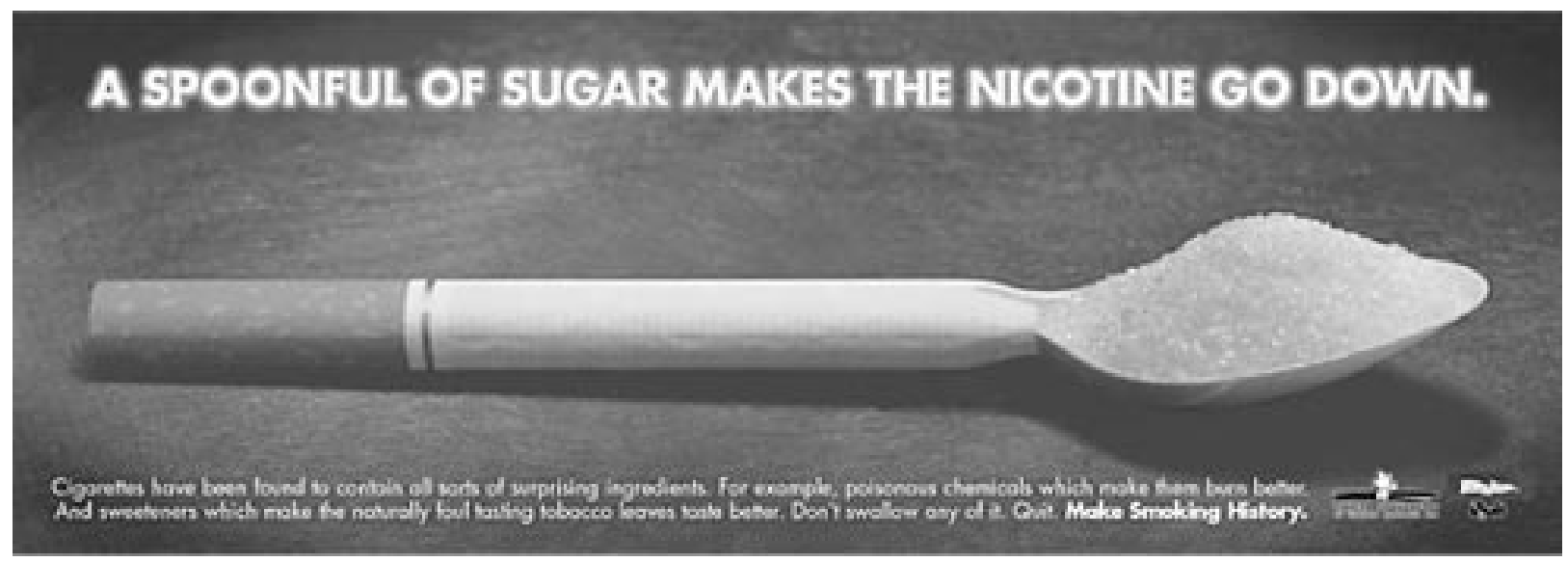

Reproduction courtesy of Cancer Foundation of Western Australia, Healthway and Quit. 